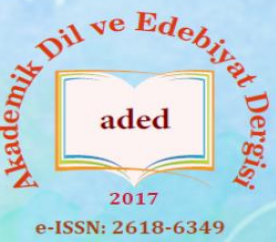

Akademik Dil ve Edebiyat Dergisi

Academic Journal of Language and Literature

Cilt/Volume: 3, Sayı/Issue: 4, (Aralık/December 2019)

USTALARA SAYGI-I:

Prof. Dr. Fatma Sabiha KUTLAR OĞUZ'a Armağan

\title{
Bir Hami Olarak Kınalızâde Ali Çelebi ve Muamma Türüne Katkısı ${ }^{*}$
}

\section{Kınalızâde Ali Çelebi as a Patron and His Contribution to the Enigma Genre}

\section{Tuba Işınsu DURMUŞ*}

Prof. Dr., TOBB Ekonomi ve Teknoloji Üniversitesi

e-mail: tdtubadurmus@gmail.com

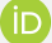

https://orcid.org/0000-0002-0796-6655

Araştırma Makalesi/Research Article

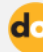

https://doi.org/10.34083/akaded.648594

Sorumlu Yazar/Corresponding Author

Tuba Işınsu Durmuş, TOBB Ekonomi ve Teknoloji Üniversitesi, Ankara/Türkiye

Geliş Tarihi/Received : 19.11.2019

Kabul Tarihi/Accepted: 12.12.2019

\section{Atıf/Citation}

DURMUŞ, Tuba Işınsu (2019). Bir Hami Olarak Kınalızâde Ali Çelebi ve Muamma Türüne Katkısı. Akademik Dil ve Edebiyat Dergisi, 3 (4), 124-140.

DOI: 10.34083 /akaded.650244
Öz

Osmanlı yöneticilerinin şair/yazarların sanat gelişimleri konusunda hami olarak destekleri ve çevrelerinde oluşturdukları edebi muhitler bilinmekle birlikte, hamilerin edebi muhitlerinde yer almış şair/yazarların belirli tür ya da konulara dair ortaklık gösterecek üretimlerinin olup olmadığı hususu, bu konu hakkında ayrıntılı değerlendirmeler yapılmadığı için çoğu zaman göz ardı edilmektedir. Bu makalede belirli isimlere koruyuculuk yaparak onların sanatlarındaki ilerlemeye destek olan hami konumundaki kişilerin bazen bir türün gelişimine de katkı sağlamış olabilecekleri hususu Kınalızâdeler ailesinden meşhur Ahlâk-1 Alâyî yazarı Kınalızâde Ali Çelebi örneği ve muamma türü üzerinden sorgulanacak ve delillendirilmeye çalışılacaktır.

Anahtar Kelimeler: Kınalızâde Ali Çelebi, hami, muamma

\section{Abstract}

Although the support of Ottoman administrators as patrons for the artistic development of poets and writers (known as "hamilik", a type of sponsorship), and the circles of poets and writers they bring together around themselves are wellknown, the question of whether the patrons engaged in collaborative production with the poets/writers within their circles is frequently ignored due to the absence of detailed analyses on this subject. In this paper we discuss the issue of and bring new evidence on the question of whether the patrons, who, by taking various names under their protection, helped them develop aristically, might also have sometimes contributed to the development of a genre themselves on the basis of a case study on Kinalizâde Ali Çelebi, a member of the Kinalızâde family and the famous author of Ahlâk-ı Alây $\hat{\imath}$, and the enigma genre.

Key Words: Kınalızâde Ali Çelebi, patron, enigma

\footnotetext{
${ }^{1}$ Bu makale, TÜBA, Üstün Başarılı Genç Bilim İnsanlarını Ödüllendirme Programı (GEBİP) çerçevesinde kabul edilen “Osmanlı Divan Edebiyatında Kim Kimdir?” başlıklı proje çalışmasının çıktılarından biridir.
} 


\section{Giriş}

Osmanlı yöneticilerinin şair/yazarların sanat gelişimleri konusunda hami olarak destekleri ve çevrelerinde oluşturdukları edebi muhitler bilinmekle birlikte, hamilerin edebi muhitlerinde yer almış şair/yazarların belirli tür ya da konulara dair ortaklık gösterecek üretimlerinin olup olmadığı hususu, bu konu hakkında ayrıntılı değerlendirmeler yapılmadığı için çoğu zaman göz ardı edilmektedir. Araştırıcılar genellikle sadece üzerinde çalıştıkları isme ve eserlerine odaklanmakta, o ismin etkilediği veya onu etkileyen başka şair/yazarlar eğer çok tanınan bir ekolün temsilcisi değilse söz konusu çalışmalara karşılaştırma yapmayı sağlayacak tespitleri dâhil etmemektedirler. Oysaki ekol oluşturan şair/yazarlar dişında bazen üslubun bazen de bir türün takipçisi olarak üretimlerine devam eden ve bir muhit oluşturan şair/yazar toplulukları da vardır. Bu makalede belirli isimlere koruyuculuk yaparak onların sanatlarındaki ilerlemeye destek olan hami konumundaki kişilerin bazen bir türün gelişimine de katkı sağlamış olabilecekleri hususu Kınalızâdeler ailesinden meşhur Ahlâk-ı Alâŷ̀ yazarı Kınalıâde Ali Çelebi örneği ve muamma türü üzerinden sorgulanacak ve delillendirilmeye çalışılacaktır.

Osmanlıda padişah saraylarının yanında sadrazam, şeyhülislam, vezir, defterdar, nişancı gibi yüksek devlet memurlarının saray ve konaklarının, devirlerinde yetişen şairlerin sığındıkları ve korundukları yerler olduğu, buna karşılık İstanbul'dan uzakta kalan şairleri de sancak merkezlerinde şehzadelerin saraylarının topladığı bilinen bir husustur. Sözü edilen bu yüksek devlet memurlarının bazılarının Osmanlıda sanat ve kültür üretimine ve tüketimine katkı sağlayan farklı mesleklerdeki sanat üreticisi ve destekleyicisi önemli aileler oldukları bilinmektedir. Osmanlı coğrafyasına yayılmış Mirzazâdeler, Zekeriyazâdeler, Hocasaadettinzâdeler, Dürrizâdeler, Çandarlılar, Fenarizâdeler, Çivizâdeler, Ebusuudzâdeler, Müeyyedzâdeler, Taşköprülüzâdeler, Bostanzâdeler, Paşmakçızâdeler, Kınalızâdeler, Arabzâdeler, Feyzullahzâdeler, Ebuishakzâdeler, İvazpaşazâdeler gibi önemli ulema ve bürokrat ailelerinin sadece sanat koruyucusu olarak değil zaman zaman icracı olarak da önemli konumları vardır. Bu ailelerden, büyük dedeleri Abdülkadir Hamîdî sakalına kına yaktığı için kınalıoğulları anlamına gelen isimle anılan Kınalızâde ailesi, Osmanlı coğrafyasının değişik yerlerinde kadı ve müderris olarak görev yapmış, aile silsilesi 15. yüzyıldan 17. yüzyıla kadar 5 kuşak takip edilebilen önemli bir ulema ailesidir. 


\section{Kınalızâde Ailesinin Şair Olarak Konumları:}

Ailenin bilinen en büyük üyesi Abdülkadir Hamîdî Efendi (ö. 1548) aldığı iyi eğitimden ve değişik yerlerde yaptığı müderrislik görevlerinden sonra (İpşirli 1988: 240) Antalya, Bursa ve İstanbul kadılıkları görevinde bulunmuş, Anadolu kazaskeri ve şeyhülislamlık görevlerinin ardından emekli olmuştur (Yılmaz 2014). Asıl adı Abdülkadir olduğu için Kâdirî mahlası ile şiirler de kaleme alan Hamîdî Efendi'nin tezkire yazarlarına göre Arapça şiir ve inşası Türkçe şiirlerinden, Türkçe şiirleri ise nesrinden daha başarılı (Kılıç 2010: 1309) olarak değerlendirilmektedir. Hamîdî Efendi'nin oğlu Emrullah Efendi (ö. 1560) Şam ve Halep'te kadılık yaptıktan sonra Piçin kadısı iken vefat eden aynı zamanda Mîrî mahlaslı bir şairdir. Necati Bey (ö. 1509) ile çağdaş olan Mîrî’nin gazellerinin çoğu şaire naziredir. Mîrî divan sahibi bir isimdir (Pektaş 2013). Emrullah Efendi'nin beş çocuğundan bilinen dördünün bürokrasideki önemli görevleri yanında hepsinin şair oluşu önemlidir. Bunlardan Mîrî Kadızâde Müslimî Efendi (ö. 1585) İstanbul'daki müderrislik görevinden başka Rodos ve Amasya'da kadılık görevlerinde bulunmuş, aynı zamanda üç dilde yazılmış şiirleri olan Müslimî mahlaslı mürettep divan sahibi bir şairdir (Kılıç 2010: 805-806). Emrullah Efendi'nin diğer bir oğlu Kınalızâde Abdülvehhab Efendi (ö.?) Gölhisar

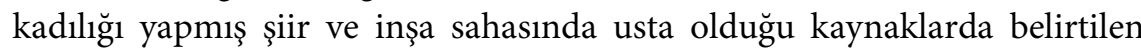
Vehhâbî mahlaslı bir şairdir. Emrullah Efendi'nin diğer bir oğlu olan Abdurrahim (ö. 1574), bazı kaynaklarda mahlasının Kirâmî (Köksal 2013) bazı kaynaklarda ise Ümîdî (Aksoyak 2015) olduğu ifade edilen bir şairdir. Müderrislik görevlerinin ardından Siroz, Ankara ve Yenişehir kadılıklarında bulunan Abdurrahim ise, divan sahibidir. Farsça ve Türkçe şiirleri vardır (Solmaz 2005: 203-204). Oğlu Vasfî mahlaslı Abdurrahimzâde Mustafa Vasfî aldığı klasik medrese eğitiminin ardından kadılık görevlerinde bulunmuş aynı zamanda şiirle de uğraşmış bir şairdir (Karagözlü 2013). Emrullah Efendi'nin Kadın adlı tek kızı hakkında eşi Abdüssemî Çelebi ve oğulları Abdulmûtî Çelebi olduğundan başka bilgimiz yoktur. Emrullah Efendi'nin oğullarından en tanınmışı Kınalızâde Alâeddin Ali Çelebi'dir. Dönemin önemli isimlerinden aldığg eğitim sonrasında Edirne, Bursa, Kütahya ve İstanbul'da değişik medreselerde müderrislik görevlerinin ardından Şam, Halep, Kahire, Bursa, Edirne ve İstanbul kadılıklarında bulunmuştur. Anadolu kazaskerliği görevinde iken vefat etmiştir (1572). Üç dilde de şiir yazabilen mürettep divan sahibi Ali Çelebi, Alî mahlası ile şiirlerle birlikte Türkçe ve Arapça birçok eser kaleme almıştır. Alaeddin Ali Çelebi'nin dört oğlu da şairdir. Bunlardan biri olan şuara tezkiresi yazarı Kınalızâde Hasan Çelebi (ö. 1604) öğrenimini tamamladıktan sonra Bursa, Edirne, Aydıncık, 
Gelibolu, Eski Zagra, Halep ve Mısır gibi çeşitli yerlerde müderrislik ve kadılık yaptı. Divan sahibi olmamakla birlikte şiirle yakından ilgilenmiş, Arapça, Farsça ve Türkçe şiirler kaleme almıştır, şiirlerine çeşitli mecmualarda rastlanmaktadır (İsen 2002: 418). Gelibolulu Âlî (ö. 1600), Künhü'l-Ahbâr'da Kınalızâde Hasan Çelebi'yi inşa tarzının yanı sıra çeşitli yönlerden eleştirse de başta Riyâzî, Rızâ, Şakâyık ve Enîsü'l-Müsâmirîn müelllifi, Hasan Çelebi'nin inşasını beğenmektedir. Sicill-i Osmânî de Hasan Çelebi'nin Abdurrahman (ö. 1629) adlı müderris bir oğlunun olduğu bilgisi de yer almaktadır (Sungurhan 2013). Alaeddin Ali Çelebi'nin bir başka oğlu Kınalızâde Mehmed Fehmî Efendi (ö. 1595) döneminin önemli bilginlerinden ve müderrislerinden aynı zamanda Fehmî mahlası ile şiirler yazan mürettep divan sahibi bir şairdir (Ördek 2014). Kınalızâde Hüseyin Feyzî Çelebi (ö. 1586'dan sonra) kadı olması yanında Feyzî mahlaslı bir şairdir (Yılmaz 2014). Oğlu Abdurrahman Efendi (ö. 1629) de çeşitli yerlerde yaptığı müderrislik görevlerinin yanında Abdî mahlaslı bir şairdir (Ekinci 2014). Alaeddin Ali Çelebi'nin bu isimlerden başka sadece Ahdî̀nin Gülşen$i$ Şuarâ'sında ismi zikredilen Kınalızâde Sıdkî Efendi adlı bir oğlu daha vardır. İlimle meşgul olduğu ve Sıdkî mahlasıyla şiirler kaleme aldığından başka Sıdkî Efendi hakkında bilgimiz yoktur (Kaplan 2014).

\section{Kınalızâde Ali Çelebi ve Edebi Muhiti}

Yukarıdaki ifadelerden de görüldüğü üzere Kınalızâde ailesinden şeceresini takip edebildiğimiz beş nesil üyelerinin tamamı şairdir ve üretici olarak edebiyat ve sanat faaliyetlerinin içindedir. Bunun da ötesinde ailenin kadı ve müderris olarak görev yaptıkları Osmanlı coğrafyasının değişik yerlerinde edebi muhit oluşturdukları, şair/yazarların üretimlerini destekledikleri ya da onları teşvik ettikleri bilinmektedir. Bu isimlerden Kınalızâde Ali Çelebi de görev yaptığı Edirne, Bursa, Kütahya, İstanbul, Şam, Kahire ve Halep’te şair/yazarlarla şairlik/yazarlık kimliği yanında hami vasfıyla da bir arada olmuştur.

Bu isimlerden Mehmed Nahîfî Efendi (ö. 1609), Isparta doğumlu şairlerden Nahîfî mahlasıyla şiirler kaleme alan müderrislik ve kadılık yapmış bir isimdir. Nahîfî̀nin medrese öğrenimi görerek Kınalızâde Ali Çelebi'den mülazım olması dışında şair hakkında fazla bir bilgimiz yoktur (Kesik 2014). 1609/10 yılında İstanbul'da vefat eden şairin Kınalızâde Ali Efendi'den hayatının hangi döneminde icazet aldığı kısmı belirsiz görünmektedir. Şairin görevi sebebiyle bulunduğu İstanbul'da vefat ettiği dikkate alınırsa Ali Çelebi'nin İstanbul medreselerinde görevde bulunduğu dönemde bir araya geldikleri muhtemeldir. Benzer şekilde Defterdar Pîr Ahmed Çelebi’nin 
oğlu, 16. yüzyılın ikinci yarısının tanınmış şair ve yazarlarından Azmî Pîr Mehmed (ö. 1582) de Kınalızâde Ali Çelebi'den mülazım olup önce Rodosçuk'ta bulunan Rüstem Paşa Medresesi'nde daha sonra 1560 yılında da İstanbul'daki Rüstem Paşa Medresesi'nde müderrislik yapmıştır (Ceyhan 2013). Şairin doğum tarihini bilmediğimiz için Kınalızâde Ali Çelebi’nin hangi görevi sırasında ondan mülazım olduğu belli değildir. Ancak Kınalızâde Ali Çelebi'nin de 1551-53 yılları arasında Azmî̀nin görev yaptığı İstanbul Rüstem Paşa Medresesi'nde müderrislik yaptı̆̆ 1 bilgisi dikkate alındığında Azmî̀nin İstanbul Rüstem Paşa Medresesi'nde Ali Çelebi’nin müderris olduğu dönemde okuduğu düşünülebilir. Emânî (ö. 1591) mahlash Rusçuklu Mustafa Çelebi de bir süre Kınalızâde Ali Çelebi'nin danişmendi olmuştur (Atik Gürbüz 2013). Emânînnin ölüm tarihi üzerinden İstanbul dışında bulunmadığı ve burada vefat ettiği bilgisi dikkate alındığında Ali Çelebi ile danişmendlik ilişkisinin Çelebi'nin İstanbul'da görevde bulunduğu dönemler arasında olması muhtemeldir. Hasan Çelebi bu isimlerden başka tezkiresinde Edirneli İlmî'den söz etmekte ve biyografide şairin babasına sunduğu kasideyi örnek olarak vermektedir. Diğer kaynaklardan farklı olarak Riyâzî, Tezkiresinde şairin Kınalızâde Ali Efendi'den mülazım olduğu bilgisini vermektedir (Kaplan 2014). Şairin Edirneli olduğu ve burada hayatını geçirdiği bilgisi dikkate alındığında Ali Çelebi'nin şairle Edirne'de müderris olduğu zaman tanışıklığı muhtemeldir.

Gelibolulu Âlî, Künhü'l-Ahbâr adlı eserinin Ali Çelebi'den söz ettiği kısmında Çelebi'yi "bahr-1 ilm ü fazl" (İsen 1994: 245) olarak tanımlamakta ve Çelebi Şam kadısı iken haftada bir gün kendisini davet edip ilgi ve rağbet gösterdiğinden bahsetmektedir. Ali Çelebi'nin Ahlâk-ı Alâyı̂̀ yi kendisinin de Enisü'l-Kulûb adlı eserleri üzerinde çalıştıkları döneme denk gelen Çelebi'nin Şam kadılığında bulunduğu zaman dilimi bu ifadelerden anlaşıldığı üzere sadece Âlî değil başka şair yazarları da koruyup kollayan bir dönemdi. Bu çerçevede Ali Çelebi'nin görev yaptığı yerlerde çevresinde edebi muhit oluşturduğu ve şair/yazarları himaye ettiği anlaşılmaktadır. $\mathrm{Bu}$ isimlerden Vücûdî mahlaslı Mehmed (ö. 1612), Kınalızâde Ali Çelebi ile en uzun süreli yakınlığı olan şairdir. Eğitiminde de Kınalızâde Ali Çelebi’nin rolü büyüktür. Şair, Kınalızâde Ali Çelebi'nin Şam, Mısır, Bursa, Edirne ve İstanbul görevlerinde ona eşlik etmiştir (Aydemir 2013). Sözü edilen şehirler Çelebi'nin kadılık görevlerine denk gelmektedir. Vücûdînnin Ali Çelebi'den 40 yıl sonra vefat ettiğini dikkate alırsak şairin Çelebi'nin yanında bulunduğu yaklaşı 10 yıllık süre şairin gençlik dönemlerine denk geliyor olmalıdır. Halil Çeltik "Halep’te Kınalızâde Hasan Çelebi'nin Şairler Meclisi” adlı makalesinde Hasan Çelebi'nin 1590-1594 yılları arasında Halep’te 
kadılık yaptığ 1 dönemde oradaki şairlerle yakından görüştügünü, onlara meclislerinde yer verdiğini ve Çelebi'nin çevresinde bir şairler topluluğu oluşturduğunu belirtmektedir (2007: 139). Hasan Çelebi'nin edebi muhitinde yer alan şairlerden birisi de Vücûdî'dir ve Çeltik bu muhitteki Hâlî Ahmed, Avnî Osman, Hayâlîzâde Ömer Efendi ve Tab'î Süleyman gibi şair/yazarlara ait bilgileri Vücûdî̀nin Hayâl u Yâr adlı mesnevisinden edindiğini söylemektedir. Bu bilgilerden Vücûdînnin Kınalızâde Ali Çelebi ile uzun birlikteliğinin ardından İstanbul'da müderrislik yaptığı, Ali Çelebi'nin vefatı sonrasında 1578 yılında tekrar Şam’a gittiği, 1590 yılında da Hasan Çelebi'nin Halep kadısı olduğunda onunla birlikte Halep'te bulunduğunu öğrenmekteyiz. Dolayısıyla bu bilgilerle Vücûdî’nin Ali Çelebi ile iletişiminin hayatının gençlik dönemlerinde denk geldiği hususu da teyit edilmiş görünmektedir.

Terzîzâde Mustafa Re'yî Efendi (ö. 1573-74) de Kınalızâde Ali Çelebi'ye yakın olan isimlerdendir. Hasan Çelebi'nin ifadesiyle "Merhûm vâlid-i mâcidün çemen-i hüsn-i terbiyetinde neşv ü nemâ ve meşầil-i ma'ârif ü fezâ'ilden iktibâs-1 nûr u ziyâ idüp mecâlis-i 'ulûm u ifâdelerine müdâvim olmagla hidmet-i şerîflerinden mülâzım olmış idi” (Sungurhan 2017: 378). Ali Çelebi tarafından himaye gören ve ondan mülazım olan Re'yî, Ali Çelebi Bursa kadısı iken de ona danişmend olmuştur (Kesik 2014). Bu bilgilere ek olarak Hasan Çelebi, Tezkiresinde babası Ali Efendi'nin Arap ve Anadolu coğrafyasında kadılık görevleri sırasında Re'yî Efendi'nin de onunla birlikte olduğunu ifade etmektedir: "Vâlid-i firdevs-mekân diyâr-1 'Arab u Rûmda kâdî vü hâkim iken hidmet-i 'arûz u mekâtibâtında dầim ve dil ü cânla âstân-1 fezâ'il-âş̧iyânında hâdim olmagla fenn-i inşâ ve kầide-i tahrîr-i hucec ü sicillâtı tahsîl ve bi'l-cümle ma'ârif-i külliye vü cüz'iyyeyi tamâm tekmîl itmiş idi" (Sungurhan 2017: 378). Hasan Çelebi'nin bu ifadesi şairin Ali Çelebi ile münasebetinin sadece Bursa ile sınırlı olmadığını Çelebi'nin Şam, Kahire ve Halep kadılığı döneminde de onunla birlikte bulunduğunu ve hayatı boyunca Ali Efendi'nin bilgi ve tecrübesinden istifade ettiğini göstermektedir. Hasan Çelebi, bu bilgilere ek olarak tezkiresinde Re'yînnin Ali Çelebi'ye sunduğu bir kasideyi de vermektedir. Gelibolulu Âlî, Künhü’lAhbâr adlı eserinde Re'yî'den "Kınalızâde Ali Çelebi'nin makbul u mer'îsi ve gâh âyine-i cemâlin gören manzûr u mer'îsi belki amme-i ulemâ şâhidbazlarınun mahbûb u râ'îsi” olarak söz etmekte ve Ali Çelebi'nin koruyuculuğunda bir şair oluşuna vurgu yapmaktadır (İsen 1994: 306). Ali Çelebi'nin Şam kadılığı görevinde irtibatta bulunduğu isimlerden bir diğeri Karaferyeli Cevherî̀dir. Asıl adı İbn-i Yemin olan şair çeşitli yerlerde kadı ve müderrislik yaptıktan sonra en son Dimetoka kadısı iken 1582/90? yılında 
vefat etmiştir (Kaplan 2014). Hasan Çelebi, Tezkiresinde babası Şam kadısı iken Cevheri'nin kafile-i hacc kadısı olarak Şam'a uğradığında şairle görüştüklerini ve irtibatta olduklarını şu ifadelerle belirtmektedir: "Vâlid-i firdevs-mekân kâdî-1 Şâm-1 şeref-'unvân iken mezbûr dahı kâfile-i hacc kâdîsı olup kâfile-i rıhletleri menzil-i Şâma nâzil oldukda aramızda merkûmla kemâl-i mahabbet ü hullet hâsıl olmış idi" (Sungurhan 2017: 281). Buradan şairin Ali Çelebi ile olduğu kadar Hasan Çelebi ile de tanışıklığ 1 olduğu anlaşılmaktadır. Hasan Çelebi'nin Tezkiresinde babasının edebi çevresinde olduğundan söz ettiği bir başka isim Güzelce Kasım Paşa Dervişi adıyla da bilinen Konyalı Derviş Çelebi'dir. Vezir Kasım Paşa'nın hizmetine girip onun kâtipliğini yapan Derviş Çelebi, Kasım Paşa'nın ölümü üzerine Lala Mustafa Paşa'ya hizmet etmeye başlamış, Paşa'nın Şam Beylerbeyi olması üzerine de onunla birlikte Şam'a gitmiş ve hayatının sonuna kadar orada kalmıştır (Gönel 2014). Hasan Çelebi, babası Şam kadısı iken şairin de Mustafa Paşa ile birlikte Şam’a geldiğini ve orada görüştüklerini ifade etmektedir: "Vâlid-i firdevs-makâm kâdî-i Medîne-i Şâm iken Mustafâ Paşa (Hazret)leri Şâma beglerbegi oldukda mezbûr dahı bile Şâma gelmiş idi. Ol takrîble mezbûr ile ülfet üzre olup diyâr-1 gurbet ü vahşetde istihkâm-1 mebânî-i müvâneset ü sohbet kılınmış idi ve peyveste kandîl-i cânı revgan-1 sadâkatle enâre ve mâ-beynimüzde müdâm rahîk-i 'atîk-i hullet peymâne-i yegânegî vü vahdet ile âvâre olınmış idi” (Sungurhan 2017: 356-57). Bu ifadelerden Derviş Çelebi'nin de Ali Çelebi'nin edebi muhitindeki isimlerden birisi olduğu anlaşılmaktadır. Vardar Yeniceli Seyyid Selman Çelebi de Ali Çelebi ile yakınlığı olması muhtemel isimlerdendir. Kaynaklar bu durumu belirtmemekle birlikte şairin hayatının bir döneminde Şam'a giderek orada bulunan Gelibolulu Âlî̀nin sohbet meclislerine katıldığ 1 bilgisini vermektedirler (Ekinci 2014). Gelibolulu Âlî̀nin Ali Çelebi'nin Şam kadısı olduğu dönemde orada olduğu bilgisi ile bu durumu birleştirdiğimizde şairin Ali Çelebi ile de tanışıklığı olabileceği muhtemeldir. Ali Çelebi'nin Şam kadılığı sırasında çevresinde bulunan isimlerden bir diğeri de Bekâyî mahlaslı Mehmed Abdülbâkî̀dir. Hasan Çelebi, Tezkiresinde "vâlid-i firdevs-mekân Şâm-1 sa'âdet-encâmda kâdî iken gelüp bu fakîr-i vâlid-i ma’ârif-semîr ile musâhabet itmiş idi" (Sungurhan 2017: 237) diyerek şairle babası yanında kendisinin de tanışıklık durumundan söz etmektedir. Ali Çelebi, Edirne kadısı iken edebi çevresinde yer alan isimlerden birisi de Ubeydî'dir. Edirneli olan şair, Çelebi’nin bu şehirdeki görevi sırasında onun çevresindeki isimlerden birisidir. Hasan Çelebi, şairle babasının ve kendisinin sohbetlerinden "Vâlid-i firdevs-mekân Edirnede hâdim-i şer'-i şerefnişân oldukda merhûm-1 merkûmla musâhabet ü ihtilât idüp niçe eyyâm cevâhir-i kelâmını iltikât üzre idük” cümlesi ile söz 
etmektedir (Sungurhan 2017: 545). Depegöz Hızır Çelebi lakabıyla tanınan Hızrî, Edirneli olması sebebiyle Ali Çelebi ile yakınlığı olan şairlerdendir. Hasan Çelebi, Tezkiresinde "Vâlid-i mâcid ile 'âlem-i şebâbdan ihtilâtı ve rişte-i kalb-i pür-inbisâtınun (hazret)-i 'aliyyü'ş-şânınun südde-i seniyye-i felek-menâtlarına hayli irtibâtı var idi” (Sungurhan 2017: 335) diyerek şairin babası ile gençliğinden tanışıklı̆̆ ve irtibatları olduğunu belirtmektedir. Hasan Çelebi’nin gençken tanışıklıkları olduğu vurgusu Ali Çelebi'nin Edirne kadıllğından çok Edirne Hüsamiye Medresesi'nde görev yaptığ 1 yıllara denk geliyor olmalıdır. Misâlî de Edirneli olması ve burada yaşaması sebebiyle Ali Çelebi'nin Edirne kadılığ 1 döneminde onun edebi çevresinde bulunmuş olması muhtemel isimlerdendir. Şehnameci Fethullah Çelebi'nin de Ali Çelebi'nin meclislerine dâhil olan bir isim olduğu bilinmektedir. Hasan Çelebi "Vâlid-i firdevs-mekânun meclis-i fazl u 'irfânında 'arz-1 metâ' itdükde görmek vâki' oldı" (Sungurhan 2017: 534) diyerek şairle babasının meclislerinden birinde tanıştığını belirtmektedir. Benzer şekilde Küçük Lütfullah Beyzâde Mehmed Neylî Efendi de Ali Çelebi'nin meclislerinde yer alan isimlerden biridir. Müderrislik ve kadılık görevlerinde bulunan Neylî, Hasan Çelebi'nin ifadesiyle "Merhûm vâlid-i firdevs-âşiyân u cennetmekânun meclis-i ifâde-i tahkîk ü îkânlarında hâzır olan" (Sungurhan 2017: 885) şairlerdendi. Ali Çelebi'nin Anadolu kazaskerliği görevinde edebi çevresinde yer alan isimler de olmuştur. Bunlardan birisi Ali Çelebi'nin hemşerisi olan Ispartalı Yoluk Mehmed Çelebizâde Mahmud Sâniî̀ Çelebi'dir. Hasan Çelebi "Vâlid-i mâcid vilâyet-i Anatolıya sadr-1 'âlî-kadr oldukda tâ Cem-i sa'âdet diyü târîh dimişdür” (Sungurhan 2017: 500) diyerek şairin bu göreve geldiği zaman Ali Çelebi’ye bir tarih söylediğini belirtmektedir.

Hasan Çelebi'nin Tezkiresinde Ali Çelebi ile yakınlı̆̆ını belirttiği ancak tarihleri dikkate aldığımızda bu duruma şüpheyle yaklaşmamız gereken bir isim daha vardır: Abdî mahlaslı Abdülvehhâb es-Sabûnî, Abdülvehhab Hemedânî (ö. 1547). Abdî, Safevî hükümdarı Şah Tahmasb'ın İran'ı istila ederek sünniler üzerine baskı kurması üzerine önce Anadolu'ya oradan Şam'a ve sonra da Mısır'a geçerek Kahire'ye yerleşmiştir. Hasan Çelebi, Tezkiresinde babası Kınalızâde Ali Çelebi ile şairin Kahire'de buluştukları ve yakın dostluk kurdukları bilgisini vermektedir: "âzim-i diyâr-1 Rûm olup ba'dehû Şâm-1 şeref-encâm ve mısr-1 Kâhirede tavattun u makâm itmiş idi. Vâlid-i mâcid fâ'iz-i sa'âdet-i Hâcetü’l-islâm ve rûy-mâl-i südde-i hazret-i seyyidü'l-enâm ile pür-ihtirâm oldukda Kâhire-i tâhirede Mevlânâ-yı mezbûr ile ki kırânü’s-sa'îdeyn vâki' olmış idi. Mezbûrun medh ü senâsı ile 'azbü'l-beyân ve ratbü'l-lisân olurlar ve 1trâ-yı ma'ârif ü ahlâkında nisâr-1 
cevâhir-i kelimât-1 pür-i'tibâr kılurlar idi" (Sungurhan 2017: 543). Hasan Çelebi'nin şairin Şam ve Kahire'de bulunduğuna ve Kahire'de babası Ali Çelebi ile görüştüğüne dair verdiği bilgiler, Ali Çelebi’nin kadılık görevlerinin Şam ve Kahire olarak devam ettiği bilgisi de dikkate alındığında uygun görünmekle birlikte Abdînin ölüm tarihinin 1547 olarak belirtilmesi böyle bir görüşmenin olabileceği hususunda şüphe oluşturmaktadır. Zira Ali Çelebi'nin Kahire kadısı olarak görev yaptığı tarih 1566-67 yıllarıdır. Kaynaklar Abdî̀nin Sevâkıbü'l-Menâkıb adlı eserini Kahire'de bulunduğu sırada mevlevihanenin kütüphanesindeki Menakıbu'l-Ârifìn'i özetleyerek Farsça olarak hazırladığı ve 1540 yılında burada tamamladığı bilgisini vermektedir (Alpaslan 1988: 286-87). Bu eseri daha sonra Türkçeye çeviren Anadolu şair/yazarları da olmuştur. İlk çevirisinin 1543 yılında Kanuni'ye takdim edildiği de bilinmektedir. Sevâkıbü'l-Menâkıb'ın kaleme alındığı 1540 yılı Ali Çelebi için meslek hayatına henüz başlamadığı bir dönemdir. Bütün bu bilgilerden hareketle şairin Ali Çelebi ile Kahire'de görüşmüş olması hususunun şüpheli göründügünü belirtmek yerinde olacaktır.

\section{Kınalıâde Ali Çelebi’nin Muamma Türüne Katkısı}

Emrullah Emrî (ö. 1575) de Kınalızâde Ali Çelebi'nin uzun yıllar muhitinde olmuş isimlerden birisidir. Hasan Çelebi'nin Tezkiresinde aktardığı bilgilere göre Ali Çelebi'nin Edirne Üç Şerefeli Medresesi'nde danişmend olduğu döneme denk gelen Emrî ile tanışıklıklarından sonra Ali Çelebi'nin Edirne kadılı̆̆ 1 döneminde de onun himayesiyle Yıldırım Bayezid Medresesi'nin tevliyeti hizmetinde bulunmuş, ömrünü tevliyet hizmetleriyle geçirmiştir. Hayatının büyük bir kısmını oralı olması sebebiyle Edirne'de geçiren Emrî, hayatının gençlik döneminde Ali Çelebi ile tanışmış ve Ali Çelebi ile muamma türünü merak ederek bu türde yazılmış olan eserleri araştırmışlardır. Ali Nihad Tarlan, Divan Edebiyatında Muamma adlı çalışmasında Edirneli Emrî Çelebi'yi bu konunun en büyük üstadı kabul etmekle birlikte Emrî̀nin muamma türüne ilgi duymasının Ali Çelebi ile bu konuda yaptıkları araştırmalar olduğuna dikkat çekmektedir. Hasan Çelebi, Tezkiresinde Anadolu sahasında muammanın ortaya çıkışından söz ederken "Diyâr-1 Rûmda evvelâ mîrâne mu'ammâ diyen ve tab'-1 mû-şikâf ile mu’ammâ-güşâ olan merhûm Emrîyle cenâb-1 vâlâ-kadrîdür" (Sungurhan 2017: 602) diyerek babası Ali Çelebi ve Emrîye dikkat çekmektedir. Hasan Çelebi, devamında bu iki ismin muamma fennine ehemmiyet verip bu hususta daha önce yazılmış eserler aradıklarını ve zürafa-yı Acemden birinde Mir Hüseyni Nişaburi’nin muamma risalesini bularak iki gün içinde risaleyi Emrî̀nin okuduğu ve Ali Çelebi'nin istinsah ettiği, risaleyi beraber tetkik ettikleri bilgisini de eklemektedir. Hasan Çelebi'nin Tezkiresinde 
aktardığı, babası Ali Çelebinin yorumuna göre o döneme kadar muamma ilmine dair bir merak Anadolu'da pek oluşmamıştı. Ali Çelebi, Emrî ile tanışıklıklarından sonra muamma meselesine kısa zamanda vakıf olduklarını belirtmektedir. Çelebi'ye göre muamma türü, Emrî ve Ali Çelebi'nin bu alanla uğraşmaları sonrasında etrafta ilgi uyandırmıştır.

$\mathrm{Bu}$ dönemden sonra Emrî kendisini muamma alanında geliştirmiş ve bu alanda şöhret bulmuştur. Kaynaklarda kendisinden "muamma-gûy" ve "muamma-küşâ" olarak söz edilen Emrînnin, birçok İranlıyı muammada geçtiği bilgisi de tekrarlanmaktadır. Yekta Saraç, Emrî̀nin 650'den fazla muamması olduğu bilgisini vermektedir (2002: 13).

Muamma türünün Anadolu sahasındaki şairleri Emrî üzerinden etkilediği bilgisi doğru olmakla birlikte Kınalızâde Ali Çelebi’nin hayatı ve Osmanlının değişik coğrafyalarında yaptığı görevler sırasında çevresinde oluşturduğu edebi muhit göz önüne alındığında dikkat çekici bir detay ortaya çıkmaktadır. Ali Çelebi'nin edebi muhitinde değişik zamanlarda yer almış yukarıda söz edilen şairlerin çoğunun muamma türüne ilgi duydukları ve bu türde eserler verdikleri tespit edilmiştir. Emrî ile muamma çalışmalarının ardından Ali Çelebi muamma pratikleri yapması yanında bir hami olarak çevresindeki şairleri de bu alana teşvik etmiş olmalı ki Çelebi’nin etrafında tesadüfle açıklanamayacak sayıda şair muamma türünde üretim yapmıştır. $\mathrm{Bu}$ isimlerden Ali Çelebi'den mülazım olan Nahîfî için kaynaklarda şiir ve inşasının güzelliği yanında muammaları ile de tanındığı bilgisi verilmektedir (Kesik 2014). Ali Çelebi Bursa kadısı iken ona danişmend olan Terzîzâde Mustafa Re'yî Efendi'nin de özellikle muammaları ile tanındığı ifade edilmektedir (Kesik 2014). Ali Çelebi ile Şam kadılı̆̆ görevi sırasında bir arada olan Gelibolulu Âlî̀nin de Divan'inda 33 adet muamması vardır. Bu durum, pek az şairin divanında bu sayıda muamma olduğu göz önünde bulundurulacak olursa, Âlî̀nin de Ali Çelebi'nin muammaya olan ilgisinden etkilenmiş olduğunu göstermektedir. Ali Çelebi'nin oğlu Mehmed Fehmî Efendi de muamma konusuna ilgi gösteren bir isimdir. 1564 yllında babasının Şam kadılığı sırasında burada dünyaya gelen ve iyi bir öğrenim gördükten sonra çeşitli yerlerde müderrislik yapan Fehmî Efendi, şiirleri ve muammalarıyla şöhret bulmuştur (Ördek 2014). Hasan Çelebi, Tezkiresinde kardeşi Fehmî Efendi’den söz ederken “tahsîl ü tekmîl-i fenn-i mu’ammâya kûşiş idüp sehl zemânda zavâbıt u kavâ'idini intikâd ile te'lîf ü terkîbinde üstâd olup bu fenn-i şerîfde dahı nâmdâr u pür-iştihâr olmışdur" (Sungurhan 2017: 685) demekte ve şairin muammalarından örnekler vermektedir. Hasan Çelebi'nin amcası olan Vehhâbî mahlaslı Abdülvehhab 
Çelebi'nin de muamma türüne ilgisi olmuştur. Hasan Çelebi, amcasından "şìr ü inşâ ve fürs ü mu'ammâ ile âşnâ" olarak söz etmektedir (Sungurhan 2017: 906). Gerek Fehmî Efendi'nin gerekse de Vehhâbî̀nin muamma türüne bu ilgisinin de diğer şairlerde olduğu gibi Ali Çelebi'den gelmesi muhtemeldir. Ali Çelebi'nin Şam kadısı iken irtibatta olduğu şairlerden Karaferyeli Cevherî de muammalarıyla tanınmış bir şairdir. Ahdî, Cevherî̀nin Farsça ve muammada iyi olduğunu belirtir ve bir muamma örneği verir (Solmaz 2005: 249). Ali Çelebi'nin Şam kadılı̆̆ı döneminde edebi çevresinde olabileceği düşünülen Seyyid Selman Çelebi'nin de inşa ilminde, muamma çözme ve söylemede maharet sahibi olduğunu kaynaklar ifade etmektedir (Ekinci 2014). Hasan Çelebi şairden "mu'ammâ-gûy u mu'ammâ-güşâlıkda şöhre-i dünyâ olmış idi” (Sungurhan 2017: 442) şeklinde söz etmekte ve biyografisinden sonra şaire ait bir muamma örneğine yer vermektedir. Ali Çelebi ve Emrî ile Çelebi'nin Edirne kadılığı döneminde görüşen Ubeydî̀nin kaynaklarda Emrî̀nin izinden giderek muamma türüne ilgi duyduğu bilgisi verilmekle birlikte bu hususta şairin Ali Çelebi ile teması da dikkate alındığında Ali Çelebi’nin edebi çevresinde bulunmuş olmasının da etkili olduğunu ifade etmek gerekir. Hasan Çelebi, şairden "fenn-i mu'ammâda dahı nâm-1 tâmmı ve şöhret-i mâ-lâ-kelâmı vardur" (Sungurhan 2017: 545-547) şeklinde söz etmekte ve şairin muammalarından örnekler vermektedir. Edirneli Misâlî de Hasan Çelebi'nin ifadesiyle "Bir kaç zemân fenn-i mu'ammâya kûşiş itmekle anda dahı hayli nâm u nişân peydâ itmiş" (Sungurhan 2017: 741) isimlerdendir. Şairin Edirneli olması hasebiyle Ali Çelebi'nin Edirne görevlerinde tanışıklıkları muhtemeldir.

Yukarıda söz edilen tarih yanlışlığı dolayısıyla Ali Çelebi ile ilişkilendirilemeyecek olan Abdî mahlaslı Abdülvehhab Hemedânî̉nin de Kahire'de muamma türünde eserler verdiği bilinmektedir. Kınalızâde Hasan Çelebi, şairin Muammeyât-ı Mîr Hüseyn Şerhi ve Muammeyât-ı Esmâu'lHüsnâ adlı Farsça eserleri olduğunu belirtmektedir. Benzer şekilde Ârifî mahlaslı Mehmet Ma'ruf Efendi de Yenişehir, Diyarbakır, Şam ve Bursa kadılı̆̆ının ardından Kahire kadılığına atanmış, 1594 yılında burada vefat etmiştir. Şair, özellikle muammaları ile tanınmıştır (Kesik 2014). Hasibî mahlaslı Güzelce Rüstem Paşazâde Hüseyin Efendi de çeşitli yerlerdeki müderrislik ve kadılık görevlerinin ardından emekliye ayrılmış ve hayatının bundan sonraki dönemini Kahire'de geçirmiştir. Şairin özellikle muamma konusunda başarılı olduğu kaynaklarda belirtilmektedir (Gürbüz 2014). Hasan Çelebi de Tezkiresinde şairin muammalarından örnek vermektedir (Sungurhan 2017: 292). Hâtemî mahlaslı İbrahim Bey de hayatının bir 
dönemini Kahire, Şam ve Halep’te geçirmiştir. Ahdî, şairi muamma alanında mahir olarak tanımlamaktadır (Kaplan 2013). Bu isimleri Kınalızâde Ali Çelebi ile ilişkilendirmek mümkün olmamakla birlikte muamma geleneği ve Kahire ilişkisi de sorgulanması gereken bir husus olarak dikkati çekmektedir. Buradan muamma türünün Kahire merkezli bir yayılım alanı olduğu da anlaşılmaktadır.

Genellikle şiir alanında görülen, şairlerin lafız temelinde bazı ipuçları vererek isimleri gizledikleri edebi muamma, ilk örnekleri Arap edebiyatında görülmekle birlikte en güzel örneklerinin Fars edebiyatında verildiği araştırmacilarca hemfikir olunan bir türdür. ${ }^{1}$ Muamma türü 12. yüzyılda ortaya çımış ancak en iyi örnekleri 15. yüzyılda Herat'ta verilmiştir. Herat ekolü Şerefeddin Ali Yezdî, Molla Câmî, Ali Şir Nevâyî ve Hüseyin Muammâyî gibi isimleri yetiştirmiştir. $\mathrm{Bu}$ isimler muamma türünün teorisini ortaya koyan eserler vermişlerdir. Buradan hareketle Osmanlı ülkesinin, başka alanlarda olduğu gibi muamma türü hakkında da Herat'ın yansıma merkezlerinden birisi olduğu söylenebilir. Fars edebiyatında müstakil bir ilim şeklinde ele alınıp kaideleri belirlenen muamma türü hakkında ilk çalışmayı Şerefeddin Ali Yezdî̀nin (ö. 858/1454) yaptığı bilinmektedir. Onun koyduğu kuralları geliştiren Abdurrahman-1 Câmî̀den sonra muamma çok rağbet edilen bir edebî tür haline gelmiş, Mîr Hüseyin b. Muhammed Şîrâzî-i Nîşấbûrî ile de en ileri seviyeye ulaşmıştır (Saraç 2005: 322). Türk edebiyatına Fars edebiyatının etkisi ile geçen muamma türünü ilk söyleyenler Ahmedî (ö. 815/1412) ve Muînî'dir. Bu türün Anadolu sahasında ilgi görüp yaygınlık kazanmasında İran ve Azerbaycan'dan gelen şairler önemli rol oynamıştır. Kınalızâde Hasan Çelebi, Yavuz Sultan Selim'in İran seferinden sonra bu ülkeden Anadolu'ya gelen ilim ve sanat erbabı arasında muamma türünde ustalaşmış pek çok kişinin bulunduğunu söyler: "Sultân Selîm ol teshîr-i memâlik-i İrân ve zabt1 bilâd-1 Âzerbâycân itdükde ol diyârun her fende sâhib-i iştihârların sernigûn itmişler idi. Ol esnâda diyâr-1 'Acemden mu'ammâ-gûy ve mu'ammâgüşâ ba'z-1 ashâb-ma'ârif gelüp mu'ammâları meşhûr u şâyi' ve matla'-1 kabûl-1 halk-1 cihândan mânend-i hûrşî̀-i rahşân tâli' olmış idi." (Sungurhan 2017: 793). Bu ifadelerden Yavuz Sultan Selim'in muamma

\footnotetext{
${ }^{1}$ Muamma türüne yönelik çalışmalar için bkz. Ali Fuat Bilkan (2000). Türk

Edebiyatında Muamma. Ankara: Akçağ Yay.; Yekta Saraç (2005). "Muamma”. İslam Ansiklopedisi. C. 30. İstanbul: TDV Yay. 322-323; Mehmet Arslan (2019). "Divan Edebiyatında Muamma, Çözülmüş Muamma Örnekleri ve Muamma Çözüm Teknikleri”. Prof. Dr. Mehmet Arslan'a Armağan. Sivas: Sivas Cumhuriyet Üniversitesi Yay.
} 
ustalarını seçme konusunda özel bir tercihinin olmadığı ancak sanatçıların geldiği coğrafyada muamma türünün o dönemde popüler bir tür olduğu sonucu çıkarılabilir. Söz konusu sanatçılarla Anadolu'da da etkinleşen ve yaygınlaşan muamma türü yöneticilerin de dikkatini çekmiş olmalı ki Yavuz Sultan Selim, Nihânî̀nin kendisine her beytinde muamma bulunan bir kaside sunmasından başka Muammâyî mahlaslı şairin kendi adına bir muamma risâlesi yazmasından hoşnut kalmıştır. Hasan Çelebi Muammâyî mahlaslı şairden söz ederken "Mu'ammâyî mezbûr dahı ol eyyâmda şâh-1 mezbûrun nâmına Mu'ammâ Risâlesi virdükde memâliki mahrûsalarında dahı bu fende sâhib-i'tibâr u iştihâr kimesneler zâhir ü bedîdâr oldugına gonçe-i hâtır-1 'âtırları hurrem ü hândân olup mezbûra üç yüz filori in'âm u ihsân itmişdür" diyerek sultanın şairin sunduğu muamma risalesini 300 flori ihsanda bulunarak ödüllendirdiğini söylemektedir (Sungurhan 2017: 793). $\mathrm{Bu}$ ifadeler muamma türünün Anadolu'da da benimsenmeye başladığını göstermektedir.

\section{Sonuç}

Muamma yazma geleneği 16. yüzylldan sonra önemini kaybetmişse de Tanzimat dönemine kadar bir edebî maharet kabul edilmiştir. Cem Sultan, Lâmiî Çelebi, Bâkî, Fuzûlî, Âlî Mustafa Efendi, Nâbî, Nahîfî, Fitnat Hanım, Sünbülzâde Vehbî muamma söyleyen şairlerden bazılarıdır. Türk edebiyatında muamma söyleyen şairlerin yanı sıra bu sahada yazılan Farsça eserleri tercüme ve şerh eden şairler de çıkmıştır. Lâmiî, Mîr Hüseyin Nîşâbûrî̀nin Esmâ'ü'l-Hüsnầsını, Sürûrî Mustafa Efendi, Bihiştî Ramazan Efendi'nin, Nevî̀ de Molla Câmî̀nin muammalarını şerh etmiş, Fuzûlî yazdığı muammalardan başka bu konuda bir de risâle kaleme almıştır (Saraç 2005: 323). Bu geleneğin 16. yüzyıldan sonra önemini kaybetmesi Anadolu şairleri arasında da bazı türlerin belirli dönemlerde desteklenmesi ve popüler olması ile açıklanabilir. Önce bir hami olarak Yavuz Sultan Selim eliyle Anadolu'ya yayılan bu tür bir başka hami olan Kınalızâde Ali Çelebi eliyle de 16. yüzyılda yaygınlaşmış ve iyi örneklerini vermiştir. Bu çerçevede bu çalışmada, Osmanlı coğrafyasında çevresinde edebi muhit oluşturan hamilerin sadece ortaya konan eserleri veya söyleyiş şekillerini değil bazen de bir türün gelişimine ortam hazırlayabilecekleri hususu vurgulanmak istenmektedir. 


\section{Kaynakça}

Aksoy, Hasan (2002 ). "Kınalızâde Ali Efendi”. İslam Ansiklopedisi. C. 25. İstanbul: TDV Yay. 416-417.

Aksoyak, İsmail Hakkı (2015). "Ümîdî, Abdurrahim Çelebi”.

http://www.turkedebiyatiisimlersozlugu.com/index.php?sayfa=deta y\&detay $=7512$

Alpaslan, Ali (1988). “Abdülvehhab es-Sabûnî”. İslam Ansiklopedisi. C. 1. İstanbul: TDV Yay. 286-287.

Arslan, Mehmet (2019). "Divan Edebiyatında Muamma, Çözülmüş Muamma Örnekleri ve Muamma Çözüm Teknikleri”. Prof. Dr. Mehmet Arslan'a Armağan. Sivas: Sivas Cumhuriyet Üniversitesi Yay.

Atik Gürbüz, İncinur (2013). "Emânî, Rusçuklu Mustafa Çelebi". http://www.turkedebiyatiisimlersozlugu.com/index.php?sayfa=deta $\mathrm{y} \&$ detay $=132$

Aydemir, Yaşar (2013). "Vücûdî, Mehmed".

http://www.turkedebiyatiisimlersozlugu.com/index.php?sayfa=deta $\mathrm{y} \&$ detay $=960$

Bilkan, Ali Fuat (2000). Türk Edebiyatında Muamma. Ankara: Akçağ Yay.

Ceyhan, Adem (2013). "Azmî, Pîr Mehmed”.

http://www.turkedebiyatiisimlersozlugu.com/index.php?sayfa=deta y\&detay $=206$

Çeltik, Halil (2007). "Halep’te Kınalızâde Hasan Çelebi'nin Şairler Meclisi". Gazi Türkiyat 1: 137-147.

Ekinci, Ramazan (2014). "Abdî, Kınalızâde Abdurrahman”. http://www.turkedebiyatiisimlersozlugu.com/index.php?sayfa=deta $\mathrm{y} \& \operatorname{detay}=2158$

Ekinci, Ramazan (2014). "Selmân/İlâhî, Seyyid Selmân Çelebi”. http://www.turkedebiyatiisimlersozlugu.com/index.php?sayfa=deta $\mathrm{y} \&$ detay $=2860$ 
Gönel, Hüseyin (2014). “Derviş, Derviş Dede, Derviş Çelebi”.

http://www.turkedebiyatiisimlersozlugu.com/index.php?sayfa=deta $\mathrm{y} \&$ detay $=1960$

Gürbüz, Mehmet (2014). “Hasibî, Güzelce Rüstem Paşazâde Hüseyin Efendi".

http://www.turkedebiyatiisimlersozlugu.com/index.php?sayfa=deta y\&detay $=4456$

İpşirli, Mehmet (1988). “Abdülkadir Hamîdî Çelebi”. İslam Ansiklopedisi. C. 1. İstanbul: TDV Yay. 240.

İsen, Mustafa (1994). Künhü’l-Ahbârın Tezkire Kısmı. Ankara: AKM Yay.

İsen, Mustafa (2002). "Kınalızâde Hasan Çelebi”. İslam Ansiklopedisi. C. 25 İstanbul: TDV Yay. 417-418.

Kaplan, Yunus (2014). "Vehhâbî, Kınalızâde Abdulvehhab Efendi". http://www.turkedebiyatiisimlersozlugu.com/index.php?sayfa=deta y\&detay $=3310$

Kaplan, Yunus (2014). "Sıdkî, Kınalızâde Sıdkî Efendi”. http://www.turkedebiyatiisimlersozlugu.com/index.php?sayfa=deta $\mathrm{y} \&$ detay $=4571$

Kaplan, Yunus (2014). “Cevherî, İbn-i Yemîn”. http://www.turkedebiyatiisimlersozlugu.com/index.php?sayfa=deta $\mathrm{y} \&$ detay $=1848$

Kaplan, Yunus (2013). "Hâtemî/Mâtemî, İbrahim Bey". http://www.turkedebiyatiisimlersozlugu.com/index.php?sayfa=deta $\mathrm{y} \&$ detay $=1121$

Kaplan, Yunus (2014). “İlmî, İlmî-i Nâzik". http://www.turkedebiyatiisimlersozlugu.com/index.php?sayfa=deta y\&detay $=2219$

Karagözlü, Volkan (2013). "Vasfî, Abdurrahimzâde Mustafa Vasfî”. http://www.turkedebiyatiisimlersozlugu.com/index.php?sayfa=deta $\mathrm{y} \& \operatorname{detay}=879$ 
Kesik, Beyhan (2014). "Nahîfî, Mehmed Nahîfî Efendi”. http://www.turkedebiyatiisimlersozlugu.com/index.php?sayfa=deta $\mathrm{y} \&$ detay $=3470$

Kesik, Beyhan (2014). “Re’yî, Terzizâde Mustafa Re’yî Efendi”. http://www.turkedebiyatiisimlersozlugu.com/index.php?sayfa=deta $\mathrm{y} \& \operatorname{detay}=3374$

Kesik, Beyhan (2014). “Ârifî, Mehmed Ma’ruf Efendi”. http://www.turkedebiyatiisimlersozlugu.com/index.php?sayfa=deta $y \&$ detay $=3216$

Kılıç, Filiz (hzl.) (2010). Âşık Çelebi, Meşâirü’ş-Şuarâ. 3 C. İstanbul: İstanbul Araştırmaları Enstitüsü Yay.

Kılıç, Filiz (2014). "Müslimî, Mîrî Kadızâde Müslimî Efendi”.

http://www.turkedebiyatiisimlersozlugu.com/index.php?sayfa=deta y\&detay $=6176$

Köksal, Mehmet Fatih (2013). "Kirâmı̂”.

http://www.turkedebiyatiisimlersozlugu.com/index.php?sayfa=deta y\&detay $=449$

Köksal, Mehmet Fatih (2013). “Abdî, Abdülvehhâb es-Sabûnî, Abdülvehhab Hemedânî".

http://www.turkedebiyatiisimlersozlugu.com/index.php?sayfa=deta $\mathrm{y} \&$ detay $=1016$

Ördek, Şerife (2014). "Kınalızâde Mehmed Fehmî Efendi".

http://www.turkedebiyatiisimlersozlugu.com/index.php?sayfa=deta y\&detay $=5923$

Öztuna, Yılmaz (1989). Devletler ve Hanedanlar, Türkiye (1074-1990). C. II. Ankara: Kültür ve Turizm Bakanlı̆̆ı Yay.

Pektaş, Mehmet (2013). "Mîrî, Emrullah". http://www.turkedebiyatiisimlersozlugu.com/index.php?sayfa=deta $\mathrm{y} \&$ detay $=404$

Saraç, Yekta (2002). Emrî Divanı. İstanbul: Eren Yay. 
Saraç, Yekta (2005). "Muamma". İslam Ansiklopedisi. C. 30. İstanbul: TDV Yay. 322-323.

Saraç, Yekta (2014). "Emrî, Emrullah”.

http://www.turkedebiyatiisimlersozlugu.com/index.php?sayfa=deta $\mathrm{y} \&$ detay $=3630$

Solmaz, Süleyman (Haz.) (2005). Ahdî ve Gülşen-i Şuarâsı. Ankara: AKM Yay.

Sungurhan, Aysun (2017). Kınalızâde Hasan Çelebi, Tezkiretü’ş-Şuarâ.

https://ekitap.ktb.gov.tr/TR-194494/Kınalızâde-hasan-celebitezkiretus-s-uara.html

Sungurhan, Aysun (2013). "Hasan Çelebi, Kınalızâde".

http://www.turkedebiyatiisimlersozlugu.com/index.php?sayfa=deta $\mathrm{y} \&$ detay $=25$

Tarlan, Ali Nihat (1936). Divan Edebiyatında Muamma. İstanbul: İstanbul Üniversitesi Yay.

Tuğluk, İbrahim Halil (2014). "Ali Çelebi, Kınalızâde". http://www.turkedebiyatiisimlersozlugu.com/index.php?sayfa=deta $\mathrm{y} \&$ detay $=6171$

Yılmaz, Kadri Hüsnü (2014). "Kâdirî, Abdülkadir Hamîdî Efendi". http://www.turkedebiyatiisimlersozlugu.com/index.php?sayfa=deta $\mathrm{y} \&$ detay $=4688$

Yılmaz, Kadri Hüsnü (2014). "Feyzî, Kınalızâde Hüseyin Feyzî Çelebi". http://www.turkedebiyatiisimlersozlugu.com/index.php?sayfa=deta $\mathrm{y} \&$ detay $=2320$ 